\title{
Kalocagathia on national values (historical context of value education)
}

\author{
H. Holos \\ Kyiv National Linguistic University, Ukraine \\ Corresponding author. E-mail: golos.anna@ gmail.com \\ Paper received 19.09.18; Accepted for publication 28.09.18.
}

\begin{abstract}
https://doi.org/10.31174/SEND-PP2018-180VI74-05
\end{abstract}
\begin{abstract}
The national value education in Ukraine currently goes about a set of values, attitudes, behaviours and competencies that a society aspires to transmit to its upcoming generation (National value education curriculum (2004). Its content holds Ukraine educators' special interest for several reasons. Firstly, despite officially presented, National value education curriculum at the majority of schools is not used as statutory guidance. That consequently leads to conclusion about no unified school quality standards for value education to fulfill. Secondly, due to 2016 school reform 'Nova Ukrainska shkola' (New Ukrainian school), lots of educators' and scholars' concerns are related to triad 'parents - school - community' cooperation which implementation is sufficiently influenced by reminiscences from previous paradigm from one hand (e.g. learning outcomes at schools remain as priority; class-room discussions lack contemporary relevant issues for youth; extra curriculum activities in comparison to Western countries are artificial, as well as insufficient; authoritarian classroom management still prevails), and the objective antinomy within Ukraine population from other (e.g. poor social status of a teacher, societal problems such as corruption, nepotism, migrant intensification among youth, do have strong negative influence on new generation outlook). As far as recent Ukrainian education system is on its molding stage and value education content is its starting point for discussion, elapsed experience of school value education development in western countries, where educational 'know-hows' occurred progressively, makes a particular interest.
\end{abstract}

Keywords: upbringing, value education, character education, moral education, vyhovannia, the content of value education.

Introduction. Although education as a social institution is as old as a history of humankind, the idea of intentional value education theorizing has been relatively new. In fact, the main turnover in education worldwide - on values - has been a result of the variety of person interdisciplinary studies reconsidered in the course of $20^{\text {th }}$ century. They gave the comprehension that neither exquisite manners, nor good education, although these are also meaningful, but moral adequacy in acts, interaction and attitudes is what indeed needed for wellbeing. Much more it becomes relevant in times of blurred norms and propaganda we face today, when person's clear selfdetermination is obligatory. In this light, contemporary schooling and value education as its integral part require not only strictly static knowledge of descriptive and normative nature, but tend to be promotive and reflective, involving learners to feel, care and experience.

Needless to say, that 'value mode' in the $21^{\text {st }}$ century classroom obviously differs from what and how it was in the past. Despite the varieties of its interchangeable names and approaches offered by educators-theorists, contemporary value education is intentionally organized under the logo 'kalocagathia on nation values'. When educational contents comprise 'wholesome core', universal, national values and criteria of morality with the stress on appropriate interactions (i.e. ideas, emotions and volition impulses exchange).

For better understanding novelties in educational practice, this article is aimed to explore the genesis of value education from the maximum generalizing point.

Historical background of value education development. Historically, upbringing as a multifaceted phenomenon that coordinates human development has passed a number of milestones. From simple mastery of a younger generation to intentional joint activity of different institutions. Each era broadcasted its socio-positive descriptors which increased over time or weakened, directly affecting morals, ideology and, consequently, the content of value education (in broad sense) by variety of its international, previous and modern terms (moral education, character education, PSHE, value education etc., vyhovannia (recent term in Ukraine). Simply put, knowledge of previous generations was reconsidered, certain traditions were preserved or vice versa - rejected. The same relates to present day schooling that is searching the ways for prosocial youth's becoming in the $21^{\text {st }}$ century.

Undoubtedly, Classical Greek paideia (education, child rearing) laid a symbolic ground for Western value education curriculum.

Having borrowed lots from previous (Babylonian, Phoenician, Egyptian) cultures, ancient Greeks managed to form their own original systems with Athens and Sparta on its first rank. Despite social regime that assumed education of some [4, p.18] and obvious variations in childrearing approaches (the Athenians placed the intellectual improvement on an extreme, whereas Lacedaemonian's lifestyle was laborious [16, p. 256], both systems were oriented toward 'kalocagathia' or what is recognized today as well-round education. Denoting integration of aesthetic 'kalos', beautiful and ethical 'agathos', good, in classic world this concept was given a great weight, distinguishing person's status and background. Intellectual refinement, either athletics and sporting activities were considered equally cherished in male rearing (female did not receive formal education, except Sparta) alongside with aspiration for beauty that the Greeks found in arts. Notably, when it came about music that at that time also covered drama, lyrics and dancing. As Plato said, 'without converse to Muses... a soul becomes weak, deaf and blind leaving a man to be ignorant, rude, without grace or politeness' [4, p.29]. But besides philosophy of 'harmony and symmetry' in education the Greeks also put great importance on knowing civic rights and responsibilities. That was carried out in Athenian ephebia and much more vividly in Spartan agoge.

Surpassing all other Greek poleis by the law-abiding nature of its citizens - 'laws and intentionally instituted poverty by Lycurgus were stronger than kings' [12 p. 70], [16, p. 256] - Sparta embodied a model of an ideal citystate for all others with accordingly constituted educa- 
tional content. With no defensive walls around the polis, the Lacedaemonians (inhabitants of Sparta) represented its 'walls' [5, p.76], hence, educational emphasis was placed on solid sense, character building, and surely military skills.

With the Roman expansion the sophisticated Greek classical traditions became Latinians' trophy, who eagerly adopted a lot of ideas and skills from Greeks. Over the time, although, the Greek idealism in educational content swiftly declines. Mainly due to utilitarian life approach of Romans. As an example it is illustrated in 'Satyricon' [13], where Echion - the old clothes dealer, expresses a desire to teach his son the law or the craft, because 'it (law) has bread and butter'. Another example is Roman politician Cicero, who in his younger years was dubbed as 'Greek', 'scholar' (Cicero was fluent in Greek) [15]. That proves Romans' inferior attitude towards Greek educational standards and focus primarily on practical applications.

Thus, deistic world perception, citizenship qualities, harmonious development of privileged class individual with further utilitarian life approach in Roman society were decisive factors in Greek-Roman society that determined the content of youth's upbringing.

After the fall of Rome new impulses of upbringing strengthen the medieval religious mono pedagogy. As a consequence of Romans' persecution of believers, antique values were notably denied at the early transitional period. It is no surprise that antique attachment to scholarship and education gradually began degenerating and was left soon in oblivion. The educational process (referred to as informal) coincided with a spiritual mission and was conducted in the form of non-institutionalized apprenticeship. The knighthood implied a boy preceding training as a page or armor bearer, the clergy required a preceding service at the monastery with learning religious practices and doctrines, a craft suggested artisan apprenticeship. Hence, education in Middle Ages was limited by theological dogma, was practically oriented, defined by corporate pedagogical subculture i.e. peasant, chivalrous, church, city, etc. [9, p. 197]. The limitations were also applied for certain characters traits. Particularly, it was only aristocracy who could be attributed with nobility, courage, courtesy. Whereas commonly desired today qualities as ambition, critical thinking, independence were atypical, without any value at all. These qualities were not only difficult to realize but also to express [6, p.12].

The breakthrough restrictions that for centuries concealed the desire to observe and study the world occurred in the Renaissance. The time when medieval consciousness was awaken by heliocentric theory, antique works renewal, Arabic philosophy with its close materialistic position, the rise of literature in vernacular and many more novelties. Correspondingly, innovation that contributed to society modernization reshaped people's view on upbringing. That resulted in emergence of 'human manufacture' concept. Theory of such matter was put forward namely by humanists, who initiated discussions of wellrounded education: V. da Feltre offered daring for his times secular advance in curriculum such as swimming, dancing, fencing and horse riding. Erasmus comprehended the sufficiency of teaching manners and etiquette: 'the child should be educated in piety'. And...: 'the basis of polite behavior is moral principles'. Montaigne demanded to place effort in education on child judgment - 'to form sound and sensible mind' [4, p. 97-100]. Finally, Comenius who incorporated kalacogathia on Christian virtues in 'Magna Didactica' became a cornerstone in the whole Western pedagogy history.

Another remarkable phenomenon in the Renaissance that drastically influenced education debates was the emergence of subjectivism. For instance, derived from medieval 'taxes/ duties', the term 'character' began to correlate in the $12^{\text {th }}$ century with the individual trait, denoting morality [8, p.206].

Thus, advances in the Renaissance initiated theoretical utopia for value education based on religious and secular motives. Although the idea of well-rounded education was welcomed with enthusiasm, it was not enough to implement it into practice due to 'immature' mass perception of a child as a sort of material to work with: tabula rasa, wax, blank sheet [2, p. 199]. Upbringing literally meant disciplining. Moreover, little was done in practice to advocate or physically save a child, especially when it went about the poor.

Two centuries later, the humanists' educational thought was expanded in more radical way by the Enlightenment philosophers and educators (R. Descartes, J.J. Rousseau, D. Diderot, F. Voltaire, I. Kant, J. Pestalozzi, A. Diesterweg ) who laid the stress on 'liberal, national, secular, egalitarian, progressive values and ideas' [17, p.3.]. Among prominent influential works dedicated to upbringing, undoubtedly, J.J. Rousseau's treatises. He set the idea of natural education and individual sensibility of child, laying the foundation for child-centered education further. Rousseau's view was shared and refined by other philosophers and educators who put into practice the idea of proactive schooling (e.g. self-government, gymnastics, work, excursions in schools of philanthropists'; Tolsoy's peasant school), the concept of culture conformity (A. Diesterweg's 'man is my first name, the German is the last'), J. Herbart's idea of personal potential and civic attitudes; J. Dewey's problem-based learning.

As in the Renaissance, the enrichment of the psychological thesaurus (namely, by the introspective terms: apathy, loneliness, sensitivity, boredom, selfishness, despair, sentimentalism, sensibility) at that time also widened educational polemics in terms of positive, supportive learning [8, p. 206].

Thus, the intellectual and cultural movement in Western Europe during the Enlightenment achieved 'victory of pragmatism over dogmatism' with the institutionalized schooling as a result. A step forward was attained by formal integration of upbringing into education, supplemented with proto modern concepts and values, common in contemporary western pedagogical systems (nationstate idea, secularism, the idea of growth etc.).

The beginning of the XX century that coincided with acute social confrontation in Europe (the World Wars) was marked with attention to value theory (H. Lotze, F. Nietzsche, W. Windelband, H. Rickert etc.). It cast some doubt upon essential life principles assessing human deeds such as humanism, civilization, culture [7, p.289]. The relationship between education and other fields of study at that time became close, defining a new type education of anthropocentric type with emphases on a 
'child - society - values' triad. As Y. Korchak [10, p.20] noted, 'the state demands patriotism, the church demands faith, the employer demands honesty, but it is all humility .... education without a child in it does not exist'.

In the post-war time significant contribution to pedagogical theory and practice was done by psychologists (K. Rogers, G. Allport, A. Maslow, F. Dalton, D. WinnikotO. Lazursky, L. Vygotsky, B. Ananiev, B. Myasishchev, O. Leontiev, O. Zaporozhets, L. Bozhovich, etc.) who added the experimental method, reinforced by pragmatism and optimism, stimulus-reaction on a cultural basis [1, p. 23]. A large part of the research in the context of child development fell on humanistic psychology (A. Maslow, C. Rogers, G. Allport) that defined 'interpersonal interactions', 'facilitation', 'attitudes', 'self-actualization' as its main concepts. As a result, a new direction of pedagogy humanistic pedagogy was founded.

In this direction the global pedagogy with common problems and values moved in post-industrial period, when the systems theory was established and fixed. Accordingly, new interdisciplinary background complicated the content of value education as integrative part of schooling, shifting the emphasis on learners socialization and enculturation [7, p. 289]. Since early 90's intentional value education under variety of its names spread through many countries. The educational content in many countries comprise of civic, moral, cultural, religious, environmental etc. values to think about, to experience and to be engaged with [11]. What has actually been a determine guideline in modern democratic societies recently.

A perspective from Ukraine. To avoid ambiguity in this paper, we incline to the use the term value education as equivalent to Ukrainian 'vyhovannia', as it reflects the most precisely the essence of activities and intentions provided in modern Ukraine school.

Contrary to Western countries, where educational projects occurred coherently, Ukraine education system went through a number of socio-political barriers (historically at different times there were politically and culturally different governments - Lithuanian, Polish, and Russian) that considerably influenced the overall Ukraine educational policy and, in turn, the Ukraine national educational ideal. In fact, 'national' (language, culture, Ukraine intellectuals) in Soviet schools used to be correlated either with nationalistic, something/someone to stay away from, either minor or rustical. This vision was deeply engraved in Soviet learners' consciousness coming close with communist propaganda, then-appropriate school childrearing approaches (use of guilt, criticizing), imperative russification of the Ukrainians due to which Ukrainian pedagogue for a long time remained forcibly deprived of its cultural fundamentals. Hopefully, without any prospects on its own land, Ukrainian educational projects were developed in diaspora (I. Ohiyenko, H. Vashchenko, S. Siropolko, E. Zhars'kyy). It is no surprisingly, that since 1991 Ukraine independence, theorists' interest to national educational ideal issue, its genesis (first formulated by $\mathrm{H}$. Vaschenko) with global trends taken into account was reemerged.

In the early 2000s to innovative educational projects that comprehend the maintenance of Ukraine education as a system, one should include 'the Ukrainian ideal' and 'the Values Code of Contemporary Ukrainian Education and development (by Omelian Vishnevsky), 'the National value education curriculum for children and adolescence' (collective works under supervision of Ph.D. Ivan Bekh) and derivated from that 'Basic guidelines for value education (grades 1-11)'. In these agenda value education has been defined as a system of interiorized values and qualities of the growing generation, which are manifested in precious attitude of learners to society, state, people, environment, work, the Self. 'Precious attitude' is attached to supportive, caring, emotionally positive disposition. Since 2004 National curriculum, attitudinal approach in Ukrainian research papers has been fixed, still dominating in papers of the last decade.

With the beginning of new educational reform ('Nova Ukraiska shkola') in 2016 intended to improve past practices, schools in Ukraine today have the task to form, to mediate, and firmly establish democratic values and norms in their students. Values education is not taught as a specific subject, it is integrated with social studies, physical education, humanities; and it is also expressed in the informal curriculum.

The following trends in Ministry of education documents regarding schooling and value education are being monitored: the establishment of value pluralism, stress on competencies and character traits development (is not new idea in Ukrainian pedagogy (K. Ushinslyi and H.Vashchenko publications on character education), school encouragement in programs design [18].

Unfortunately, despite the school extra curriculum activities are much enjoyed by nearly all the students, value education is still viewed by majority of parents and learners as a low status study. Among factors that significantly affect value education at schools are: artificial school climate, social pathology toleration (bullying, social inequalities); the lack of relevant class-room discussions; minor attention to arts, music, sports; poor schoolcommunity cooperation.

Conclusion. Despite views on teaching ethics and morals at different times were variable, relying on different dominants, in the $21^{\text {st }}$ century theories on value education tend to be neither monistic, nor deterministic. What emphasized is interaction of biological, social and psychological components in person's development and real practices $v s$ abstract-ideological theory [3, p.58].

Considering multinational, multicultural, and mobile world we live in, it is clear that contemporary value education is more that rules to know and terms to clarify, it extrapolates beyond classroom with a diverse range of values to experience and act upon. Undoubtedly, crucial role and responsibility is allotted to all stakeholders learners, parents, community and the state, as all of them are the 'wheels of the same vehicle'.

With the regard to new education reform undergoing in Ukraine, we believe, one should not neglect in the name of rationality the educational 'achievements' (either new, or the best) in truly democratic societies, where youth prosocial school activities, practices and strategies are resourceful and successfully applied on sound basis. We consider theoretical and practical research in this direction, as necessary. 


\section{REFERENCES}

1. Allport, G. (1968). Selected essays. Boston: Beacon.

2. Ariers, P. (1999). L'Enfant et la vie familiale sous l'Ancien Régime, Paris, 1975 ( $1^{\text {re }}$ éd. 1960$)$

3. Berkowitz, M.W. (2002). The science of character education. In W. Damon (Ed.), Bringing in a new era in character education. Stanford CA: Hoover Institution Press.

4. Compayre, G. (1898) The history of pedagogy. Boston D.C.: Heath and company.

5. Goldsmith, O. (1836). Pinnock's Improved edition of Dr. Goldsmith's History of Greece. Key and Biddle.

6. Greenblatt, S. (2011). The Swerve: How the World Became Modern. New York: W. W. Norton.

7. Kagan, M. (1996). Filosofiya kul'turi [The phylosophy of culture ]. Sankt-Peterburg, Russia: Sankt-Peterburgskiy universitet.

8. Kon, I. (1978). Otkrytiye "ya" ["Self" discover]. Moscow, Russia: Politizdat.

9. Kon, I. (2017). Malchik - otets muzhchiny [A boy is a father of a man]. Moscow, Russia: AST.

10. Korchak, Y. (2016). Yak l'ubyty dytynu [How to love a child]. Harkiv, Ukraine: Klub simeinogo dozvillya.

11. Lickona, T. (1993). The Return of Character Education. Educational Leadership 51 (3). Available online: www.ascd.org/readingroom/edlead/9311/lickona.html.
12. Petraki, A. (2010) Reflections of Antiquity in the Greek Education of the 20th Century. Social change review, vol. 8, Issue 1, June 2010. DOI: 10.1515/scr-2016-0007

13. Petronius, A. (1913). Satyrikon. Retrieved from: http://data.perseus.org/citations/urn:cts:latinLit:phi0972.phi00 1.perseus-eng 1:45

14. Plato. (1969). Republic. Retrieved from: http://data.perseus.org/citations/urn:cts:greekLit:tlg0059.tlg03 0 .perseus-eng 1:3.393e

15. Plutarkh. (1919). Cicero. Retrieved from: https://archive.org/stream/plutarchslives07plut\#page/82/mode /2up

16. Rollin, M. (1834). Ancient history of the Egyptians, Carthaginians, Assyrians, Babylonians, Medes and Persians, Grecians and Macedonians. London: Printed for Thomas Tegg and Son, Cheapside.

17. Zafirovski, M. (2011) The Enlightenment and Its Effects on Modern Society By Milan. New York: Springer. DOI: 10.1007/978-1-44-19-73-87-0

18. Official website of Ministry of Education and Science of Ukraine: https://mon.gov.ua 